\title{
Structure of Myocardium of Young Rats With Simulated Alimentary Obesity Following the Application of Combined Rhythmic Extreme Cold Effects and Cryopreserved Cord Blood Nucleated Cells
}

Реферат: На сегодняшний день накоплено большое количество данных, свидетельствующих о положительном влиянии ритмического экстремального охлаждения (РЭХВ) $\left(-120^{\circ} \mathrm{C}\right)$ и препаратов, полученных из кордовой крови, как на разные органы, системы, так и на организм в целом. На экспериментальной модели алиментарного ожирения (АО) изучены гистологические особенности тканей и сосудов сердца, проведена гистохимическая оценка состояния коллагеновых и эластических волокон миокарда молодых крыс до и после сочетанного применения РЭХВ и криоконсервированных ядросодержащих клеток кордовой крови человека (кЯСК КК). Установлено, что для структурной организации миокарда молодых крыс с АО были характерны выраженные патологические изменения, связанные с нарушением кровообращения. Выявлялись полнокровие и тромбоз сосудов, диапедезные кровоизлияния, гипертрофия миокарда, интерстициальный и периваскулярный отеки, очаговый кардиосклероз. На 7- и 30-е сутки после сочетанного применения 9 сеансов РЭХВ и кЯСК КК отмечалась нормализация морфологической структуры сердца: пролиферация фрибробластов, свидетельствующая о развитии процессов неоангиогенеза, а также диффузное распространение гистиоцитов, менее выражены кардиосклероз, периваскулярный и интерстициальный отеки.

Ключевые слова: алиментарное ожирение, крысы, ритмические экстремальные холодовые воздействия, ядросодержащие клетки кордовой крови, кардиомиоциты, кардиосклероз, липидоз.

Реферат: На сьогоднішній день накопичено велику кількість даних, які свідчать про позитивний вплив ритмічного екстремального охолодження (РЭХВ) $\left(-120^{\circ} \mathrm{C}\right)$ і препаратів, отриманих із кордової крові, як на різні органи, системи, так і на організм у цілому. На експериментальній моделі аліментарного ожиріння (АО) вивчено гістологічні особливості тканин і судин серця, проведено гістохімічну оцінку стану колагенових і еластинових волокон міокарда молодих щурів до і після сумісного застосування РЕХВ і кріоконсервованих ядровмісних клітин кордової крові людини (кЯВК КК). Встановлено, що для структурної організації міокарда молодих щурів із АО були характерні виражені патологічні зміни, пов'язані з порушенням кровообігу. Виявлялися повнокров'я і тромбоз судин, діапедезні крововиливи, гіпертрофрія міокарда, інтерстиціальний і периваскулярний набряки, осередковий кардіосклероз. На 7- і 30-ту добу після сумісного застосування 9 сеансів РЕХВ і кЯВК КК відзначалася нормалізація морфологічної структури серця: проліферація фібробластів, що свідчило про розвиток процесів неоангіогенезу, а також дифузне поширення гістіоцитів, менш виражені кардіосклероз, периваскулярний та інтерстиціальний набряки.

Ключові слова: аліментарне ожиріння, щури, ритмічні екстремальні холодові впливи, ядровмісні клітини кордової крові, кардіоміоцити, кардіосклероз, ліпідоз.

Abstract: To date, a large amount of data has been accumulated, indicating a positive effect of rhythmic extreme cooling $\left(-120^{\circ} \mathrm{C}\right)$ and medical products obtained from cord blood, both on different organs, systems, and on the whole body. The histological features of the tissues and blood vessels of the heart were studied in the experimental model of alimentary obesity. The appearance of collagen and elastic fibers of the myocardium of young rats before and after the combined application of rhythmic extreme cold exposures (RECEs) and cryopreserved preparation of cord blood nucleated cells (CBNCs) was histochemically assessed. It has been found that the structural organization of the myocardium of young rats with obesity was characterized by pronounced pathological changes associated with impaired blood circulation. Plethora and thrombosis of blood vessels, diapedemic hemorrhages, myocardium hypertrophy, interstitial and perivascular edema, focal cardiosclerosis were revealed. To days 7 and 30 after the combined use of 9 sessions of the RECEs and CBNCs, the normalization of heart morphological structure was noted. In the interstitial connective tissue we have observed a proliferation of fibroblasts, diffuse spread of histiocytes, which indicated the development of neoangiogenesis processes, less expressed cardiosclerosis, perivascular and interstitial edema.

Key words: alimentary obesity, rats, rhythmic extreme cold exposures, cord blood nucleated cells, cardiomyocytes, cardiosclerosis, lipidosis.

Відділ кріосрізіології, Інститут проблем кріобіології та кріомедицини НАН України, Харків
Department of Cryophysiology, Institute for Problems of Cryobiology and Cryomedicine of the National Academy of Sciences of Ukraine, Kharkiv, Ukraine
*Автор, якому необхідно надсилати кореспонденцію: вул. Переяславська, 23, м. Харків, Україна 61016; тел.: (+38 057) 373-74-35, фракс: (+38 057) 373-59-52 електронна пошта: elena_chernyavskaya@ukr.net

\author{
*To whom correspondence should be addressed \\ 23, str. Pereyaslavska, Kharkiv, Ukraine 61016; \\ tel.:+380 57373 7435, fax: +380 573735952 \\ e-mail: elena_chernyavskaya@ukr.net \\ Received September, 12, 2017 \\ Accepted May, 28, 2018
}

(c) 2018 E.A. Chernyavskaya et al. Published by the Institute for Problems of Cryobiology and Cryomedicine

This is an Open Access article distributed under the terms of the Creative Commons Attribution License (http://creativecommons.org/licenses/by/4.0), which permits unrestricted reuse, distribution, and reproduction in any medium, provided the original work is properly cited. 
По оценке комитета экспертов ВОЗ ожирение считается неинфекционной «эпидемией XXI века» и одним из основных факторов риска смертности населения планеты [2]. Ожирение называют «болезнью болезней», поскольку оно сопровождается заболеваниями сердечно-сосудистой системы (артериальная гипертензия, атеросклероз, ишемическая болезнь сердца, инсульт), опорно-двигательного аппарата, инсулинзависимого сахарного диабета $[13,14]$.

Наиболее неблагоприятным в прогностическом плане является ожирение с первичным (алиментарным) фактором патогенеза, которое встречается в $70-85 \%$ случаев [11]. Основной причиной развития алиментарного ожирения (АО) считается нарушение энергетического баланса, а именно несоответствие между энергетическими поступлениями в организм и их затратами. Несомненна также роль наследственно-конституциональной предрасположенности, возрастных, половых и профессиональных факторов, характера пищевого поведения, дисфункций нервной и эндокринной систем $[14,19]$.

При ожирении в организме происходят метаболические, гормональные, гемодинамические нарушения, вызывающие структурные и функциональные изменения сердечной мышцы. У тучных людей адаптация сердечной деятельности происходит за счет формирования эксцентрической гипертрофии левого желудочка, которая является предрасполагающим фактором для развития острого инфаркта миокарда, внезапной смерти и застойной сердечной недостаточности $[2,11]$.

В настоящее время в медицине существуют различные взгляды относительно методов лечения и реабилитации пациентов с избыточной массой тела и ожирением [21]. Общеизвестно [1], что использование в терапии ожирения только одного лечебного фактора зачастую оказывается недостаточным, поскольку данное заболевание сопровождается множеством патологий: нарушением обмена веществ, снижением общей резистентности организма, гормональным дисбалансом, психосоматическими расстройствами $[13,20]$. Поэтому актуальным является поиск новых концептуальных подходов к патогенетической немедикаментозной терапии данного заболевания.

Одним из таких подходов может быть криотерапия, основанная на общем холодовом воздействии, индуцирующем позитивные сдвиги на организменном уровне $[1,21]$. Доказана высокая эффективность применения экстремальных криовоздействий $\left(-120^{\circ} \mathrm{C}\right)$ для коррекции функционального состояния лиц, испытывающих хроническое утомление, трудности с физиологической и психологической адаптацией,
According to the WHO Expert Committee, obesity is considered to be a noninfectious epidemic of the $21^{\text {st }}$ century and one of the main risk factors for mortality of the planet's population [2]. Obesity is called 'a disease of the diseases', because it is accompanied with disorders of the cardiovascular system (arterial hypertension, atherosclerosis, ischemic heart disease, stroke), musculoskeletal system, insulin-dependent Diabetes mellitus $[17,18]$.

The most prognostically unfavorable is an obesity with a primary (alimentary) factor of pathogenesis, which occurs in $70-85 \%$ of cases [16]. The main cause of the development of alimentary obesity (AO) is the energy misbalance, namely, the mismatch between energy intakes to a body and their expenditures. The role of hereditary-body type predisposition, age, sex and occupational factors, the nature of eating behavior, dysfunctions of nervous and endocrine systems is also undoubted $[13,18]$.

Obesity is accompanied with metabolic, hormonal, hemodynamic disorders, causing structural and functional changes in the heart muscle of an organism. In obese people an adaptation of cardiac activity occurs due to the formation of eccentric hypertrophy of the left ventricle, which is a predisposing factor for the development of an acute myocardial infarction, sudden death and congestive heart failure $[2,16]$.

Currently, medical scientists have different opinions about the methods of treatment and rehabilitation of patients with an excessive body weight and obesity [11]. It is well known [1], that the use of just one therapeutic factor in the treatment of obesity is often insufficient, since the disease is accompanied with a number of pathologies: metabolic disorders, decrease in a general resistance of the organism, hormonal imbalance, psychosomatic disorders [10, 17]. Therefore the search for new conceptual approaches to the pathogenetic non-drug therapy of this disease is urgent.

One of these approaches could be cryotherapy based on the general cold effect inducing positive shifts at the organismal level $[1,11]$. The high efficiency of the use of extreme cryoeffects $\left(-120^{\circ} \mathrm{C}\right)$ to correct a functional state of the individuals experiencing a chronic fatigue, difficulties with physiological and psychological adaptation, acclimatization [20] has been proven. We believe the main mechanisms of preventive and therapeutic action of extreme cryotherapy are associated with stimulation of physiological reserves of the body, optimization of neurohumoral regulation and metabolism, increase in nonspecific resis-ance [7].

Cell therapy using the stem cells (SCs) is one of the most promising directions in progress of medicine, which allows obtaining absolutely new cli- 
акклиматизацией [22]. По нашему мнению, основные механизмы профилактического и терапевтического действия экстремальной криотерапии связаны со стимуляцией физиологических резервов организма, оптимизацией нейрогуморальной регуляции и обмена веществ, повышением неспецифической резистентности [3].

Клеточная терапия с использованием стволовых клеток (СК) - одно из наиболее перспективных направлений развития медицины, позволяющих получить качественно новые клинические результаты [10]. Наиболее легкодоступным источником получения СК является кордовая (пуповинная) кровь (КК) $[9,15]$. Научные открытия последних десятилетий в области биологии, фундаментальной и клинической медицины доказывают высокую медико-биологическую ценность КК как важного источника биологически активных веществ и СК, которые успешно используются при лечении различного рода патологических состояний, в том числе и заболеваний сердечно-сосудистой системы, сопутствующих АО [12].

На основе результатов научных исследований, проведенных в ИПК и К НАН Украины, была разработана технология выделения [6] и криоконсервирования ядросодержащих клеток кордовой крови (ЯСК КК) [7], позволяющая сохранять в жизнеспособном состоянии до 85\% ядросодержащих $\left(\mathrm{CD} 45^{+}\right)$ и до 98\% гемопоэтических стволовых (CD34 $\left.{ }^{+}\right)$клеток.

Физиологические особенности реакций организма, а также его функциональных систем на ритмическое экстремальное охлаждение $\left(-120^{\circ} \mathrm{C}\right)$ и введение крио-консервированных ЯСК КК позволяют не только индивидуальное, но и совместное их использование. При этом возможно взаимное потенцирование их влияния на организм [3, 4].

До настоящего времени исследования, касающиеся изучения механизмов комбинированного влияния РЭХВ $\left(-120^{\circ} \mathrm{C}\right)$ и препаратов, полученных из КК, на адаптационно-компенсаторные резервы организма экспериментальных животных при $\mathrm{AO}$, не проводились. В связи с этим результаты изучения сочетанного влияния РЭХВ и криоконсервированных ЯСК КК на структурно-функциональное состояние тканей и сосудов миокарда при АО позволяют обосновать целесообразность их терапевтического применения для профилактики развития сердечно-сосудистых заболеваний.

Цель работы - оценить морфологическое состояние тканей и сосудов сердца экспериментальных животных с моделью алиментарного ожирения до и после сочетанного применения ритмических экстремальных холодовых воздействий $\left(-120^{\circ} \mathrm{C}\right)$ и криоконсервированных ядросодержащих клеток кордовой крови. nical results [14]. The most available source of SCs derivation is cord (umbilical) blood (CB) [9, 19]. Scientific discoveries of the recent decades in the field of biology, basic and clinical medicine have proven the high medical and biological value of the $\mathrm{CB}$ as an important source of biologically active substances and SCs, which are successfully used in the treatment of various pathologies, including diseases of the cardiovascular system [15].

Based on the results of scientific research carried out at the Institute for Problems of Cryobiology and Cryomedicine of the National Academy of Sciences of Ukraine, there was developed the technology for isolating [6], and cryopreservation of CBNCs [5], allowing to preserve viability of up to $85 \%$ of nucleated $\left(\mathrm{CD}^{4} 5^{+}\right)$and up to $98 \%$ of hematopoietic stem cells $\left(\mathrm{CD}^{+} 4^{+}\right)$.

The physiological characteristics of the responses of the body and its functional systems to rhythmic extreme cooling $\left(-120^{\circ} \mathrm{C}\right)$ and introduction of cryopreserved CBNCs allow not only single but also combined application. In this case, mutual potentiation of their influence on the organism is possible $[3,7]$.

For this moment no studies have been performed to investigate the mechanisms of the combined effect of $\operatorname{RECE}\left(-120^{\circ} \mathrm{C}\right)$ and the preparations obtained from SCs on the adaptive-compensatory reserves of the body of experimental animals during the AO. In this regard, the study of the combined effect of RECE and cryopreserved CBNCs on structural and functional state of tissues and blood vessels of the myocardium at AO makes possible to justify the advisability of their therapeutic use for the prevention of the development of cardiovascular diseases.

The research aim was to assess the morphological state of the tissues and blood vessels of experimental animals with the modeled alimentary obesity before and after combined application of rhythmic extreme cold effects $\left(-120^{\circ} \mathrm{C}\right)$ and cryopreserved cord blood nucleated cells.

\section{Materials and methods}

Studies were performed in outbred white young 6-month male rats. The experiments were carried out in accordance with the Law of Ukraine on the Protection of Animals Against Cruelty (№ $3447-$ IV dated of 21.01.2006), meeting the requirements of the Committee for Bioethics of the Institute, agreed with the statements of the European Convention for the Protection of Vertebrates Used for Experimental and Other Scientific Purposes (Strasbourg, 1986).

The animals were divided into three groups $(n=7$ in each): 1 - intact; 2 - rats with the simulated $\mathrm{AO}$; 


\section{Материалы и методы}

Исследования выполняли на белых молодых 6-месячных нелинейных крысах-самцах.

Эксперименты проводили в соответствии с Законом Украины «О защите животных от жестокого обращения» (№ 3447-IV от 21.01.2006 г.) при соблюдении требований Комитета Института по биоэтике, согласованных с положениями «Европейской конвенции о защите позвоночных животных, используемых для экспериментальных и других научных целей» (Страсбург, 1986).

Животные были разделены на группы ( $n=7$ в каждой): 1 - интактная; 2 - крысы с моделью АО; 3 животные с АО после комбинированного применения РЭХВ и криоконсервированных ЯСК КК.

Ожирение моделировали по методике В.Г. Баранова, предусматривающие содержание животных на гиперкалорийном рационе [8]. Степень ожирения у крыс [18] определяли по значимому увеличению весоростового показателя - индекса Ли, который рассчитывается по формуле:

$\sqrt[3]{ }$ вес тела (г) / длина от носа до анального отверстия (см) $\times 1000$ (отн. ед).

Величина индекса более 300 отн. ед. свидетельствует о наличии ожирения.

После подтверждения наличия АО животным проводили сеансы РЭХВ и вводили криоконсервированные ЯСК КК.

Ритмические холодовые воздействия осуществляли в метрологически аттестованной криокамере для охлаждения экспериментальных животных [5]. Установка состоит из следующих узлов: термоизолированный корпус с рабочей камерой, в которой расположены теплообменник с заливным клапаном и каналом для отвода хладагента; рабочий отсек с герметичной шторкой, в середине которого размещено устройство для фиксации животного; датчики для регистрации температуры и контроля функционального состояния животных; герметично закрывающийся шлюзовой отсек, позволяющий избежать значительного градиента температур между рабочей камерой и рабочим отсеком. Для контроля температуры в камере использовали платиновые метрологически аттестованные термометры сопротивления («Гера», Украина).

Животных помещали через шлюзовой в основной отсек криокамеры (рабочий режим $-120^{\circ} \mathrm{C}$ ) на 2 мин, где за ними осуществлялся постоянный визуальный контроль через специальное окно, затем их содержали 5 мин при комнатной температуре $\left(22-24^{\circ} \mathrm{C}\right)$ вне камеры. Процедуру охлаждения повторяли: крыс согревали 5 мин при комнатной температуре, далее цикл охлаждений проводили по аналогичной схеме. Всего в сутки животные получали три процедуры РЭХВ. Во время отогрева следили
3 - animals with AO after the combined application of RECE and cryopreserved CBNCs.

Obesity was simulated according to the method of V.G. Baranov by keeping the animals on a hypercaloric diet [8]. The degree of obesity in rats [12] was examined by a significant increase in the weightgrowth index, the Lee index, which is calculated by the formula:

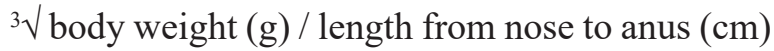
$\times 1000$ (rel. units).

If the index is more than 300 rel. units the obesity is present.

After confirming the AO presence the animals were treated with RECE and injected with cryopreserved CBNCs.

Rhythmic cold effects were performed in a metrologically certified cryochamber for cooling the experimental animals [4]. The assembly consists of the following units: a thermally insulated shell with an operating chamber, wherein a heat exchanger with a filling valve and a channel for the discharge of the refrigerant is located; a working compartment with a sealed curtain, in the middle of which there is a device for fixing the animal; sensors for recording temperature and monitoring the functional state of animals; a hermetically sealed lock chamber, which avoids a significant temperature gradient between the operating chamber and working compartment. To monitor the temperature in the chamber, platinum metrologically validated resistance thermometers («Gera», Ukraine) were used.

The animals were placed through a lock chamber into the main compartment of cryochamber (operating mode of $-120^{\circ} \mathrm{C}$ ) for $2 \mathrm{~min}$, where they were monitored via a special window, afterwards they were kept for 5 minutes at room temperature $\left(22-24^{\circ} \mathrm{C}\right)$ outside the chamber. The cooling procedure was repeated: the rats were warmed for 5 minutes at room temperature, later the cooling cycle was repeated in the same manner. In total the animals received three RECE procedures daily. During warming up, the behavior of the animals was monitored. To days 3 and 5 the RECE sessions were repeated. Animals were subjected to a 9-fold cooling ( $2 \mathrm{~min}$ each) at a temperature of $-120^{\circ} \mathrm{C}$ for 5 days.

Taking into account the previously obtained experimental data indicating an increase in the permeability of the blood-brain barrier to biologically active substances [7], the RECE course was accompanied by the CBNC introduction after the sixth cooling procedure. A ready-made preparation of the cryopreserved CBNCs was introduced to rats with the experimental AO. This preparation was a suspension of cryopreserved human CBNCs in autological plasm with a concentration of stem cells of 
за поведением животных. На 3-и и 5-е сутки сеансы РЭХВ повторяли. Животные в течение 5 дней подвергались 9-кратному охлаждению (по 2 мин каждое) при температуре $-120^{\circ} \mathrm{C}$.

С учетом ранее полученных экспериментальных данных, свидетельствующих о повышении проницаемости гематоэнцефалического барьера для биологически активных веществ на фоне РЭХВ [3], ЯСК КК вводили после шестой процедуры охлаждения.

Крысам с моделью АО вводили готовый препарат криоконсервированных ЯСК КК, который представлял собой взвесь криоконсервированных ЯСК КК в аутоплазме с концентрацией стволовых CD34+-клеток 2-4 × $10^{5}$ в 1 мл [6, 7]. Размороженные ЯСК КК вводили однократно внутрибрюшинно в дозе $3 \times 10^{5} \mathrm{CD}_{34}^{+}-$-клеток в расчете на килограмм массы тела животного.

Животных всех групп выводили из эксперимента путем декапитации на 7- и 30-е сутки после последнего сеанса РЭХВ и введения ЯСК КК. Сразу после этого сердце животного разрезали в поперечном направлении по венечной борозде, выделенную каудальную часть (желудочки) исследовали гистологическими методами [16].

Материал фиксировали в 10\%-м растворе нейтрального формалина, обезвоживали в спиртах возрастающей концентрации (от 50 до $100^{\circ}$ ), пропитывали смесью спирта и ксилола (1:1), ксилолом, смесью ксилола и парафина (1:1), парафином, а затем заключали в парафиновый блок.

С помощью санного микротома («Reichert», Австрия) изготавливали гистологические срезы (толщина 5-7 мкм) в плоскости, перпендикулярной длинной оси сердца. После депарафинирования в ксилоле срезы окрашивали гематоксилином Ганзена и эозином, помещали в полистирол под покровное стекло.

Окраску соединительной ткани выполняли по методу Ван Гизона с использованием красителя пикрофуксина (насыщенный раствор пикриновой кислоты и 1\%-й раствор кислого фуксина в соотношении 1:10). При этом клеточные ядра докрашивали железным гематоксилином Вейгерта, после чего срезы помещали в полистирол под покровное стекло.

Для выявления липидов, кроме стандартных гистологических исследований, проводили окрашивание поперечных срезов желудочков сердца гистохимическим методом с использованием красителя масляного красного (судан красный 5В). Методику окрашивания липидов выполняли в соответствии с рекомендациями изготовителя набора «Масляный красный O» («Bio-Optica Milano SpA», Италия). Для сохранения фосфолипидов выделен-
2-4 $\times 10^{5} \mathrm{CD}^{2} 4^{+}$cells in $1 \mathrm{ml}[5,6]$. Thawed CB NCs were intraperitoneally administered once at a dose of $3 \times 10^{5} \mathrm{CD} 4^{+}$cells per kilogram of body weight of an animal.

The animals of all the groups were sacrificed by decapitation to days 7 and 30 after the last RECE session and administration of CBNCs. Immediately afterwards the animal's heart was cut in a transverse direction through the coronary groove, the isolated caudal part (ventricles) was histologically examined [21]. The sample was fixed in a $10 \%$ solution of neutral formalin, dehydrated in alcohols with an ascending concentration (from 50 to $100^{\circ}$ ), impregnated with a mixture of alcohol and xylene (1: 1), xylene, xylene and paraffin (1:1), paraffin, and then was enclosed into a paraffin block.

With the help of a sledge microtome (Reichert, Austria) the histological sections (5-7 microns thick) were made in a plane perpendicular to the long axis of the heart. After dewaxing in xylene, the sections were stained with Hansen's hematoxylin and eosin, placed in polystyrene under a cover glass.

The connective tissue was stained using the Van Gieson method using the picrofuchsine dye (a saturated solution of picric acid and 1\% solution of acidic fuchsine in a ratio of $1: 10$ ). At the same time, the cell nuclei were additionally stained with Weigert's iron hematoxylin, after which the sections were placed in polystyrene under a cover glass.

For the detection of lipids, in addition to standard histological studies, staining of the transverse ventricular sections of the heart was carried out histochemically using Oil red dye (Sudan red 5B). The lipid staining procedure was performed in accordance with the recommendations of the manufacturer of the Oil Red O kit (Bio-Optica Milano SpA, Italy). To preserve the phospholipids, the isolated fragments of the heart of the experimental animals were fixed in Baker's formalin-calcium solution $(10 \mathrm{ml}$ of $40 \%$ formalin, $90 \mathrm{ml}$ of distilled water, $1 \mathrm{~g}$ of calcium chloride). Sections of $5 \mu \mathrm{m}$ thick were obtained with a freezing microtome using a cryospray (Bio-Optica Milano SpA) and placed into gelatin under a cover glass. Neutral triglycerides and lipids were colored red thereat.

Studies and microphotography of histological sections were carried out with a light microscope AxioStar Plus (Carl Zeiss, Germany) using digital camera (Canon Power Shot A610, Japan) and the computer software AxioVision Rel. 4.6 (Carl Zeiss Imaging Solution GmbH, Germany), as well as in the Olympus BX63 microscope (Olympus Corporation, Japan) using a digital camera Olympus DP73 and the software CellSens Dimension (Olympus Soft Imaging Solution $\mathrm{GmbH}$, Germany). Resolution of the obtained images 
ные фрагменты сердца экспериментальных животных фиксировали в кальций-формоловом растворе по Бейкеру (10 мл 40\%-го формалина, 90 мл дистиллированной воды, 1 г хлорида кальция). Срезы толщиной 5 мкм получали на замораживающем микротоме с использованием криоспрея («Bio-Optica MilanoSpA», Италия) и помещали в желатин под покровное стекло. Нейтральные триглицериды и липиды окрашивались в красный цвет.

Исследования и микрофотографирование гистологических срезов проводили в световом микроскопе «AxioStar Plus» («Carl Zeiss», Германия) с использованием цифровой фотокамеры («Canon Power Shot A610», Япония) и компьютерной программы «AxioVision Rel. 4.6» («Carl Zeiss Imaging Solution $\mathrm{GmbH»,} \mathrm{Германия),} \mathrm{а} \mathrm{также} \mathrm{в} \mathrm{исследовательском}$ микроскопе «Olympus BX63» («Olympus Corporation», Япония) при помощи цифровой фотокамеры «Olympus DP73» и компьютерной программы «CellSens Dimension» («Olympus Soft Imaging Solution GmbH», Германия). Разрешение полученных изображений $898 \times 673$ и $1600 \times 1200$ пикселей при $\times 200,400$ и окуляре $10 \times$.

\section{Результаты и обсуждение}

Результаты гистологического исследования тканей миокарда интактных животных подтвердили адекватность применяемых методик. Структурная организация сердечной мышцы соответствовала норме [17].

При гистологическом исследовании сердца молодых крыс с моделью АО установлено, что граница между эпикардом и миокардом выражена нечетко из-за проникновения жировой ткани вглубь миокарда в виде тяжей жировых клеток по ходу венозных сосудов и капилляров. Определялись диапедезные кровоизлияния (рис. 1, А). В местах наиболее выраженного ожирения соединительнотканных прослоек между истонченными мышечными волокнами ядра кардиомиоцитов были гипохромны (атрофия от давления), поперечная исчерченность не выявлялась (рис. 1, В).

В более глубоких отделах миокарда, где жировая ткань отсутствовала, мышечные волокна имели признаки гипертрофии, о чем свидетельствовало увеличение массы саркоплазмы кардиомиоцитов, размеров их ядер (гипертрофия ядер). Ядра кардиомиоцитов были гиперхромными, их количество относительно кардиомиоцитов интактных животных увеличивалось (рис. 2, А). При этом размеры кардиомиоцитов также увеличивались. Одновременно сгипертрофией миокарда разрастались волокнистые структуры стромы (очаговый кардиосклероз) (рис. 2, В).

При окрашивании масляным красным, который применяется для выявления в клетках нейтраль-
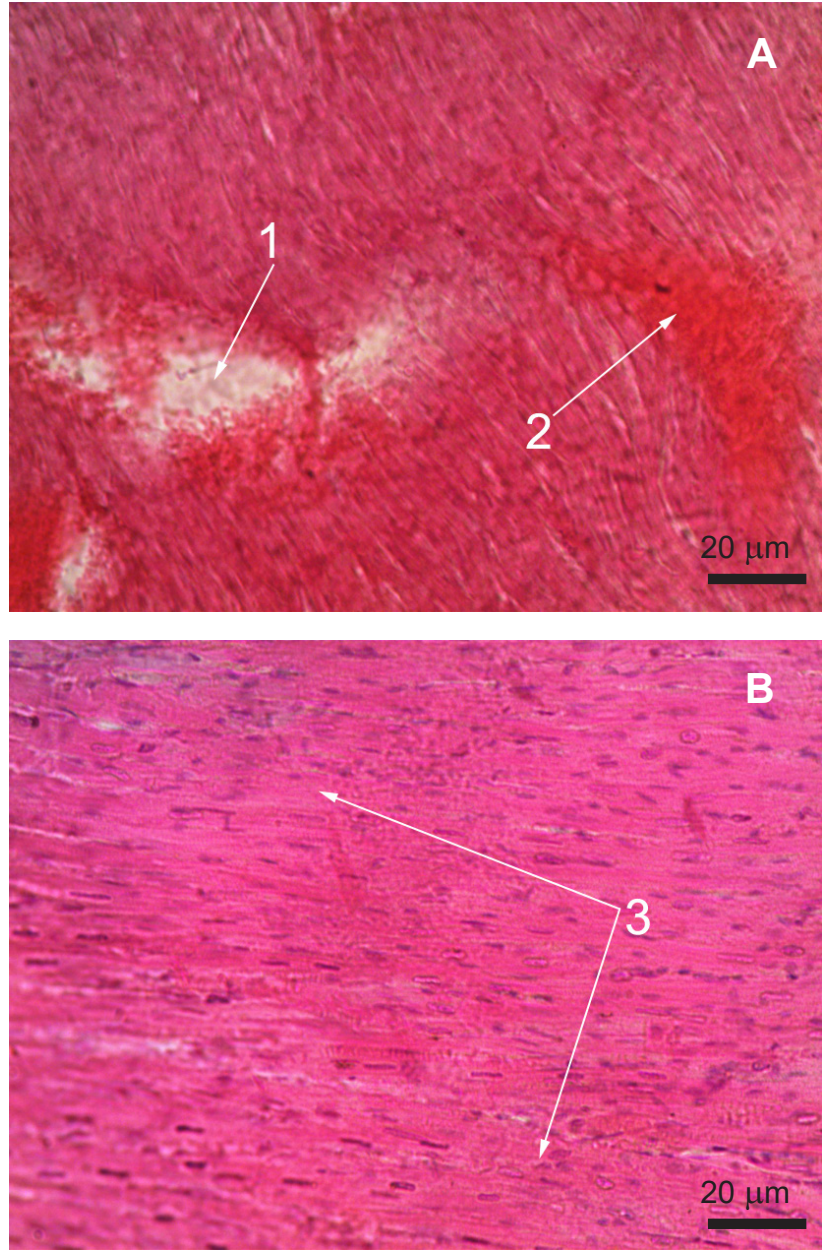

Рис. 1. Участки миокарда левого желудочка молодых крыс с моделью АО: А - жировые клетки между миокардиоцитами (1), диапедезные кровоизлияния (2); В атрофия миокардиоцитов (3). Окраска гематоксилином и эозином.

Fig. 1. Sites of left ventricular myocardium in young rats with AO model: A - fat cells between myocardiocytes (1), diapedesis hemorrhages (2); B - atrophy of myocardiocytes (3). Staining with hematoxylin and eosin.

was $898 \times 673$ and $1600 \times 1200$ pixels at $\times 200,400$ and $10 \times$ eyepiece.

\section{Results and discussion}

The results of histological examination of intact animals' myocardial tissues confirmed the adequacy of the methods used. The structural organization of the cardiac muscle corresponded to the norm [22].

During histological examination of the heart of young rats with the experimental AO it was established that the border between the epicardium and myocardium was not clearly expressed due to the penetration of fatty tissue into the interior of the myocardium in the form of fat cells cords along the course of venous vessels and capillaries. Diapedesis hemorrhages were found (Fig. 1A). In the sites of the most pronounced obesity, the connective tissue layers between the 

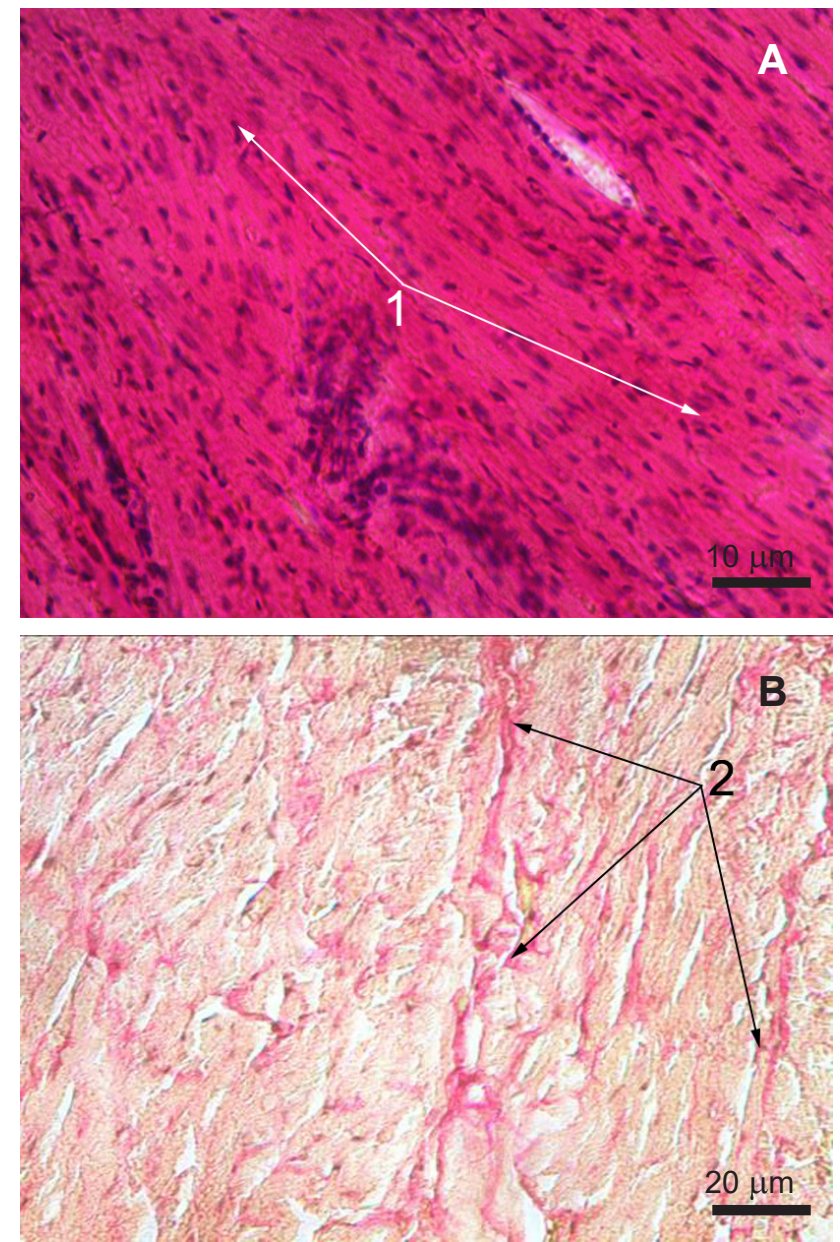

Рис. 2. Участки миокарда левого желудочка молодых крыс с моделью АО: А - гипертрофия кардиомиоцитов (1) в глубоких отделах миокарда. Окраска гематоксилином и эозином; В - разрастание волокнистых структур стромы (2). Окраска пикрофуксином по Ван Гизону.

Fig. 2. Sites of left ventricular myocardium in young rats with AO model: A - cardiomyocyte hypertrophy (1) in deep sections of myocardium. Staining with hematoxylin and eosin; B - proliferation of stroma fibrous structures (2). Picrofuchsin staining by Van Gieson.

ных триглицеридов и липидов, в цитоплазме истонченных кардиомиоцитов обнаруживались очень мелкие (пылевидное ожирение) (рис. 3, А) и редкие мелкие (мелкокапельное ожирение) жировые капли красного цвета (рис. 3, В).

Таким образом, морфологическая картина миокарда молодых животных с моделью АО свидетельствовала о развитии нарушений кровообращения (полнокровие и тромбоз сосудов, диапедезные кровоизлияния, гипертрофия миокарда, интерстициальный и периваскулярный отеки, очаговый кардиосклероз). О наличии ожирения свидетельствовали пылевидные и мелкокапельные скопления липидных включений, определяемые специфическим окрашиванием на нейтральные жиры красным масляным. thin muscle fibers of cardiomyocyte nucleus were hypochromic (pressure resulted atrophy), transverse striation was not observed (Fig. 1B).

In deeper parts of the myocardium, where fatty tissue was absent, the muscle fibers had the signs of hypertrophy, as evidenced by an increase in the mass of the sarcoplasm of cardiomyocytes, as well as in the size of their nuclei (the nuclei hypertrophy). The nuclei of cardiomyocytes were hyperchromic, their number versus intact animals increased (Fig. 2A). At the same time, the size of cardiomyocytes was also increased. Simultaneously with hypertrophy of the myocardium the stroma fibrous structures (focal cardiosclerosis) grew (Fig. 2B).
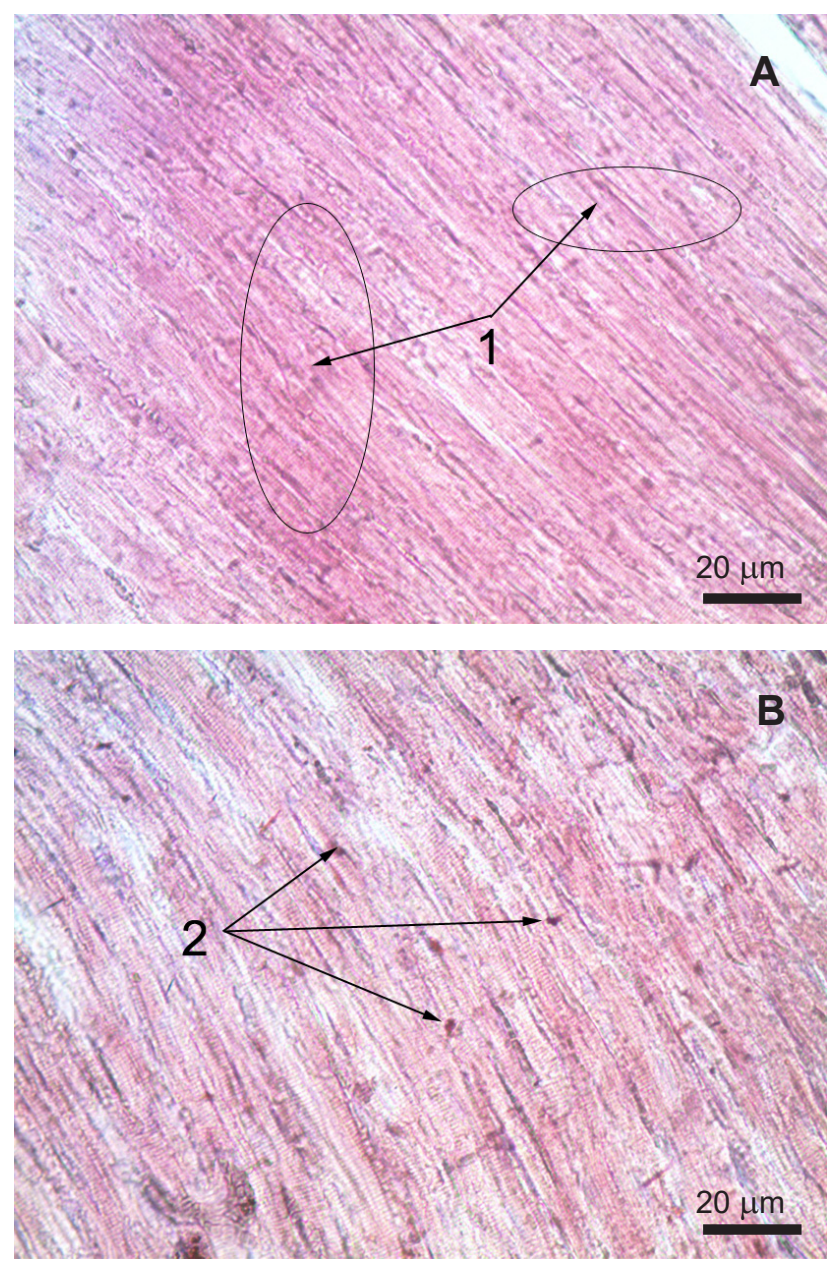

Рис. 3. Участки миокарда левого желудочка молодых крыс с моделью АО: А - очень мелкие жировые капли красного цвета в цитоплазме кардиомиоцитов (пылевидное ожирение) (1); В - редкие мелкие жировые капли красного цвета (мелкокапельное ожирение) (2) на фоне пылевидных липидных включений. Окраска масляным красным.

Fig. 3. Sites of left ventricular myocardium of young rats with $\mathrm{AO}$ model: $\mathbf{A}$ - very small fat drops of red color in cytoplasm of cardiomyocytes (dusty obesity) (1); B - rare small fat drops of red color (small droplet obesity) (2) on background of dusty lipid inclusions. Staining with oil red. 
Через 7 суток после сочетанного применения девяти процедур РЭХВ и введения криоконсервированных ЯСК КК гистологическое исследование миокарда 6-месячных крыс с моделью АО выявило относительно равномерную толщину мышечных волокон, которые ветвились и образовывали между собой анастомозы с плотной сетью, характерной для нормальной структуры сердечной мышцы, при этом поперечная исчерченность кардиомиоцитов местами отсутствовала. В тонких прослойках интерстициальной соединительной ткани наблюдались пролиферация фибробластов, свидетельствующая об неоангиогенезе, а также диффузное распространение гистиоцитов. Признаки интерстициального отека и кардиосклероза не обнаруживались. В то же время имело место полнокровие сосудов (рис. 4, А). При окрашивании тканей и сосудов миокарда пикрофуксином по Ван Гизону отмечалось распространение тонких коллагеновых волокон интерстициальной ткани, что подтверждало образование новых капилляров (рис. 4, В).

После окрашивания масляным красным обнаруживалась жировая дистрофия миокарда в виде пылевидного накопления липидов в цитоплазме кардиомиоцитов. Липидные включения имели бледно-розовый цвет (рис. 5).

На 30-е сутки после сочетанного применения РЭХВ и криоконсервированных ЯСК КК у молодых животных с моделью АО отмечалась нормальная структура сердечной мышцы. Пространства между кардиомиоцитами с отчетливой поперечной исчерченностью были заполнены рыхлой волокнистой соединительной тканью. В ней выявлялись диффузно расположенные фибробласты с плотным ядром веретенообразной формы, а также многочисленные капилляры, заполненные форменными элементами крови. Наблюдались единичные интерстициальные отеки. Кардиомиоциты имели светлые овальные и несколько удлиненные базофильные ядра, количество которых было болыше по сравнению с контрольной группой (рис. 6, А). Цитоплазма кардиомиоцитов эозинофильная, окрашивалась равномерно. Эндотелиоциты имели уплощенную форму с вытянутыми ядрами. При окрашивании пикрофуксином по Ван Гизону в интерстиции миокарда обнаруживались зрелые коллагеновые волокна яркорозового цвета, расположенные вдоль мышечных волокон (рис. 6, В). Вокруг сосудов располагались пучки коллагеновых волокон, ориентированных концентрично.

При окрашивании масляным красным выявлялась жировая дистрофия миокарда в виде мельчайшего (пылевидного) накопления липидов в цитоплазме кардиомиоцитов. Липидные включения имели бледно-розовый цвет (рис. 7).
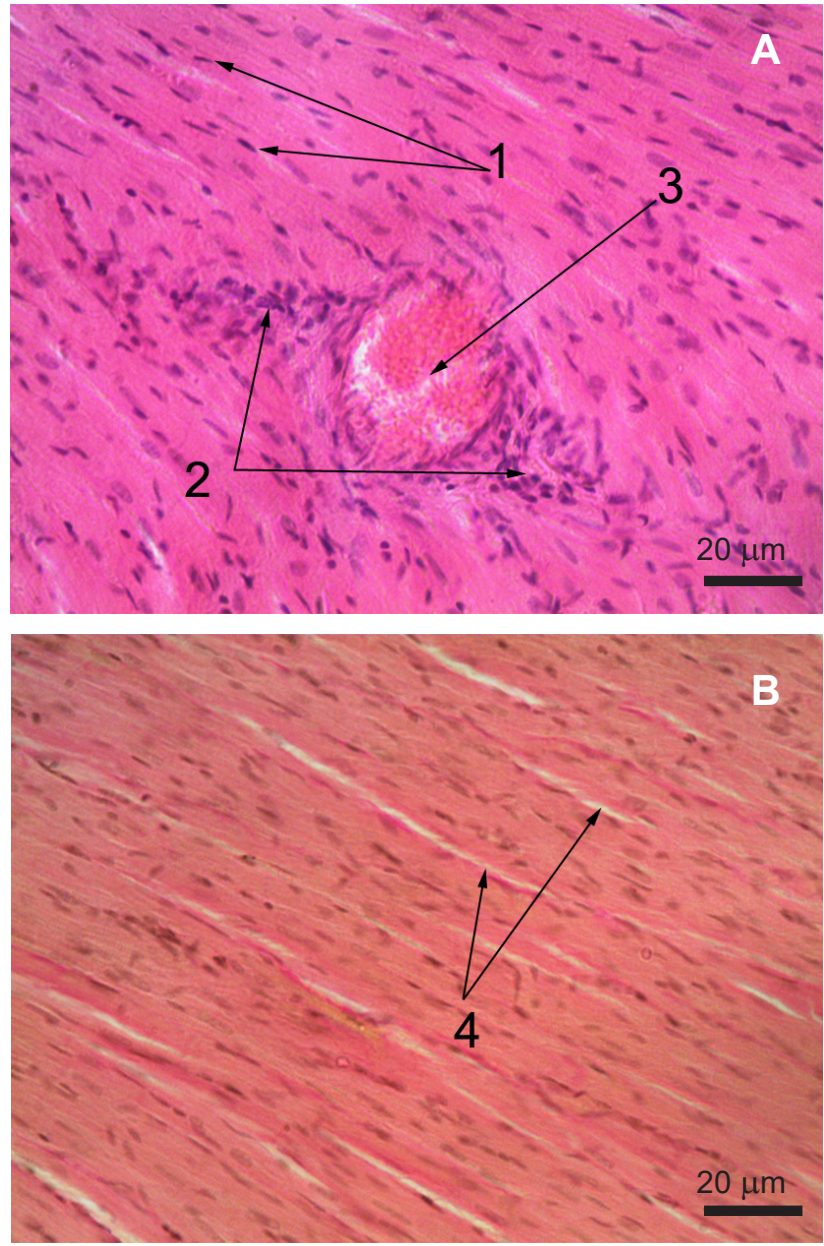

Рис. 4. Участки миокарда левого желудочка молодых крыс с моделью АО на 7-е сутки после сочетанного применения РЭХВ и криоконсервированных ЯСК КК: A - фрибробласты (1) между пучками кардиомиоцитов и вновь сформированные капилляры (2), мелкие сосуды заполнены кровью (3). Окраска гематоксилином и эозином; В - нежные коллагеновые волокна (4) интерстиция (розового цвета) между мышечными волокнами. Окраска пикрофуксином по Ван Гизону.

Fig. 4. Sites of left ventricular myocardium of young rats with the AO model to day 7 after combined application of RECE and cryopreserved CBNCs: A - fibroblasts (1) between bundlesof cardiomyocytes and newly formed capillaries (2), small vessels filled with blood (3). Staining with hematoxylin and eosin; B - tender collagen fibers (4) interstitium (pink) between muscle fibers. Picrofuchsin staining by Van Gieson.

Staining with Oil red, which is used to detect neutral triglycerides and lipids in cells, showed very small (dusty obesity) (Fig. 3A) and rare small (small droplet obesity) fatty drops of red color in the cytoplasm of thinned cardiomyocytes (Fig. 3B).

Thus, the myocardium morphology of young animals with the experimental AO indicated the development of circulatory disorders (plethora and thrombosis of vessels, diapedesis hemorrhages, myocardial hypertrophy, interstitial and perivascular edema, focal cardiosclerosis). The presence of obesity was indicated by 


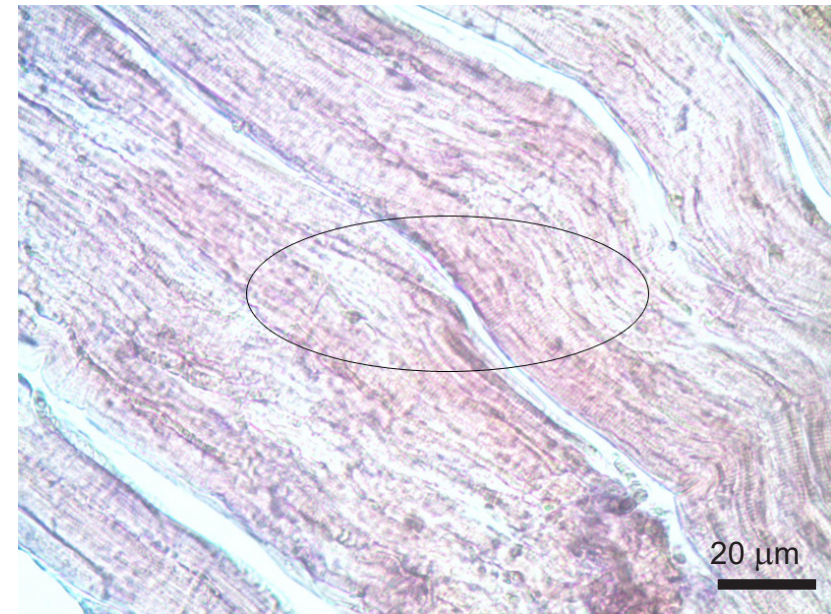

Рис. 5. Пылевидное накопление липидов в цитоплазме кардиомиоцитов. Участки миокарда левого желудочка молодых крыс с моделью АО на 7-е сутки после сочетанного применения РЭХВ и криоконсервированных ЯСК КК. Окраска масляным красным.

Fig. 5. Dust-like accumulation of lipids in cytoplasm of cardiomyocytes. Sites of left ventricular myocardium of young rats with $A O$ model to day 7 after combined application of RECE and cryopreserved CBNCs. Staining with oil red.

Таким образом, на 7- и 30-е сутки после сочетанного применения молодым животным с моделью АО девяти сеансов РЭХВ и криоконсервированных ЯСК КК отмечалась нормализация морфологической структуры миокарда за счет улучшения кровообращения и трофики сердечной мышцы. Признаки интерстициального отека и кардиоскле- pulverous and small droplet lipid inclusions, determined by specific staining for neutral fats with Oil red.

Seven days after the combined use of nine RECE procedures and introduction of cryopreserved CBNCs a histological study of the myocardium of 6-month-old rats with the experimental $\mathrm{AO}$ revealed a relatively uniform thickness of the muscle fibers that branched and formed an anastomosis with a dense network characteristic of the normal structure of the cardiac muscle. This transverse striation of cardiomyocytes was absent in some areas. In thin layers of interstitial connective tissue a proliferation of fibroblasts, indicative of neoangiogenesis, as well as diffuse spread of histiocytes were observed. No signs of interstitial edema and cardiosclerosis were found. At the same time, a vasoconstriction was present (Fig. 4A). Staining the tissues and blood vessels of the myocardium with picrofuchin according to Van Gieson revealed the dissemination of fine collagen fibers of interstitial tissue, which confirmed the formation of new capillaries (Fig. 4B).

Oil red staining revealed a fatty myocardial dystrophy in the form of dusty accumulation of lipids in the cytoplasm of cardiomyocytes. Lipid inclusions were of pale pink color (Fig. 5).

To day 30 after the combined application of RECE and cryopreserved CBNCs in young animals with the experimental $\mathrm{AO}$, the normalized structure of the cardiac muscle was noted. The spaces between the cardiomyocytes with distinct transverse striation were filled with a loose fibrous connective tissue. It had diffu-
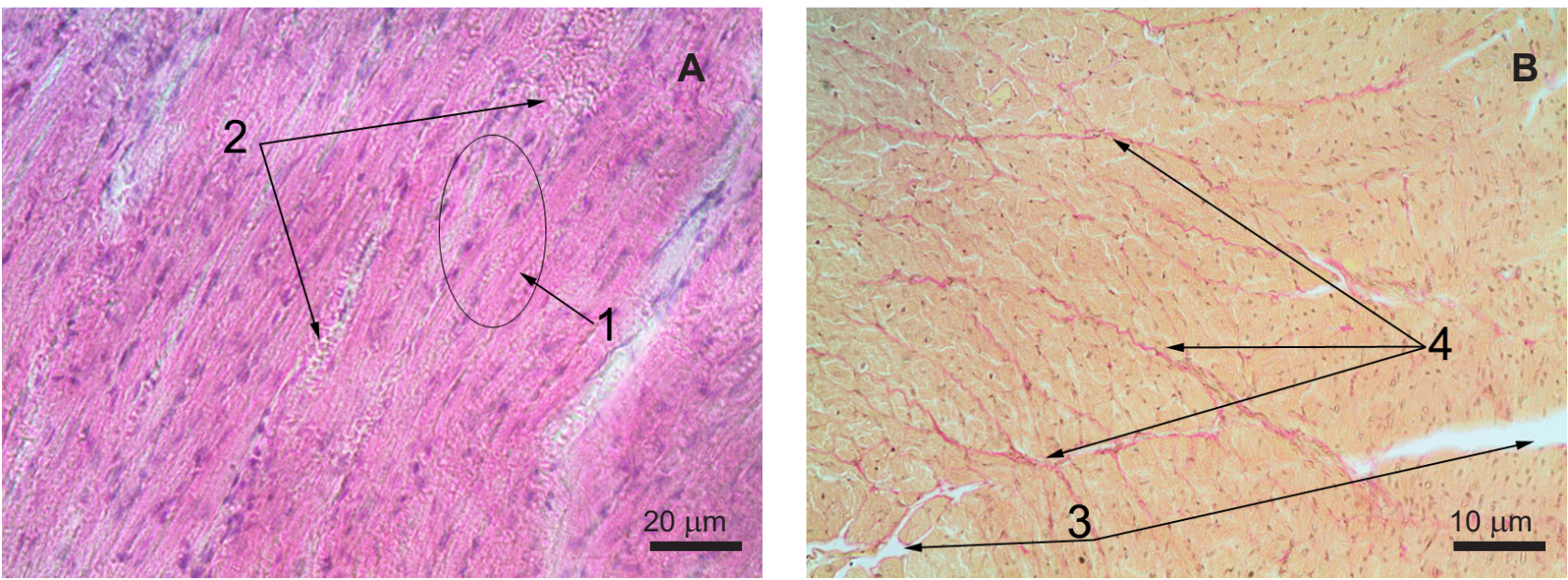

Рис. 6. Участки миокарда левого желудочка молодых крыс с моделью АО на 30-е сутки после сочетанного применения РЭХВ и криоконсервированных ЯСК КК: А - кардиомиоциты с поперечной исчерченностью и увеличенным количеством светлых ядер (1), многочисленные капилляры, заполненные фрорменными элементами крови (2). Окраска гематоксилином и эозином; В - умеренные интерстициальный отек (3) и кардиосклероз (4). Окраска пикрофруксином по Ван Гизону.

Fig. 6. Sites of left ventricular myocardium of young rats with $A O$ model to day 30 after combined application of RECE and cryopreserved CBNCs: A - cardiomyocytes with transverse striation and increased number of light nuclei (1), numerous capillaries filled with formed elements of blood (2). Staining with hematoxylin and eosin; B moderate interstitial edema (3) and cardiosclerosis (4). Picrofuchsin staining by Van Gieson. 


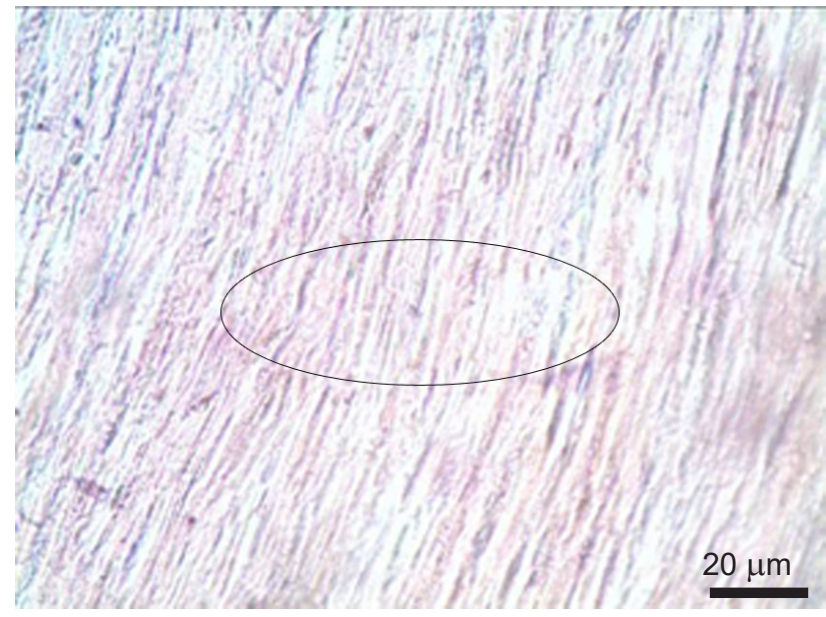

Рис. 7. Пылевидное накопление липидов в цитоплазме кардиомиоцитов. Участки миокарда левого желудочка молодых крыс с моделью АО на 7-е сутки после сочетанного применения РЭХВ и криоконсервированных ЯСК КК. Окраска масляным красным.

Fig. 7. Dust-like accumulation of lipids in cytoplasm of cardiomyocytes. Sites of left ventricular myocardium of young rats with $A O$ model to day 7 after combined application of RECE and cryopreserved CBNCs. Staining with oil red.

роза были слабо выражены по сравнению с таковыми у крыс контрольной группы. В интерстициальной соединительной ткани имели место пролиферация фибробластов, диффузное распространение гистиоцитов, являющиеся морфологическими признаками неоангиогенеза. Положительный эффект сочетанного влияния РЭХВ и ЯСК КК подтверждает выявленное при окрашивании гистологических препаратов масляным красным снижение степени выраженности жировой дистрофии миокарда. Важно, что через месяцпосле сочетанного воздействия липидоз у молодых экспериментальных животных приобретал черты обратимого процесса.

На сегодняшний день в литературе обсуждается вопрос о целесообразности применения экстремального охлаждения и клеточной терапии для лечения различных заболеваний. Результаты проведенных нами экспериментальных исследований согласуются с литературными данными $[4,20]$, при этом они позволяют более широко раскрыть механизм развития ожирения и комбинированного влияния на него РЭХВ $\left(-120^{\circ} \mathrm{C}\right)$ и криоконсервированных ЯСК КК, а также обосновать перспективность их совместного использования с целью профилактики сопутствующих АО патологий. По нашему мнению, одним из возможных механизмов возникновения АО у молодых животных является развитие морфофункциональных нарушений в тканях и сосудах миокарда, которые проявляются их полнокровием и тромбозом сосудов, диапедезными кровоизлияниями, интерстициальным и периваскулярным отеками, очаговым sely located fibroblasts with a dense core of spindleshaped form, as well as numerous capillaries filled with blood cells. Single interstitial edemas was observed. Cardiomyocytes had light oval and somewhat elongated basophilic nuclei, the number of those was larger in comparison with the control group (Fig. 6A). Cytoplasm of cardiomyocytes was eosinophilic, evenly stained. Endoteliocytes had a flattened shape with elongated nuclei. Staining with picrofuchsin according van Gieson, revealed mature, collagen fibers of bright pink color, located along the muscle fibers in myocardial interstitium (Fig. 6B). Around the vessels the bundles of collagen fibers were oriented concentrically.

Staining with Oil red showed fatty degeneration of the myocardium in the form of a minute (dust-like) accumulation of lipids in the cytoplasm of cardiomyocytes. Lipid inclusions were of a pale pink color (Fig. 7).

Thus to days 7 and 30 after the combined application of nine RECE sessions and cryopreserved CBNCs to young animals, the normalized myocardium structure was noted in terms of improved blood circulation and trophism of the heart muscle. The signs of interstitial edema and cardiosclerosis were poorly expressed in comparison with those in the rats of the control group. The interstitial connective tissue showed the proliferation of fibroblasts, diffuse spread of histiocytes, which are morphological signs of neoangiogenesis. The positive effect of the combined effect of RECE and CBNCs was confirmed by the revealed during staining of histological samples with Oil red decrease in the manifestation of fatty dystrophy of the myocardium.

It is worth to note that a month after the combined effect the lipidosis in young experimental animals had a signs of a reversible process.

Nowadays the expediency of application of extreme cooling and cell therapy for treatment of various diseases is widely discussed in the literature. The results of our experimental studies are consistent with the published reports $[3,10]$, and moreover they allow us to clear up the mechanism of obesity development and how this could be affected by of RECE $\left(-120^{\circ} \mathrm{C}\right)$ and cryopreserved human CBNCs introduction, as well as to justify the prospect of their combined application with the purpose of prevention of accompanying pathologies. In our opinion, one of the possible mechanisms of $\mathrm{AO}$ in young animals is the development of morphofunctional disorders in the tissues and vessels of the myocardium, which are manifested by vascular plethora and thrombosis, diapedesis hemorrhages, interstitial and perivascular edemas, focal cardiosclerosis. The combined use of RECE $\left(-120^{\circ} \mathrm{C}\right)$ and cryopreserved human CBNCs 
кардиосклерозом. Сочетанное применение РЭХВ $\left(-120^{\circ} \mathrm{C}\right)$ и криоконсервированных ЯСК КК позволяет нормализовать структуру сердечной мышцы, поскольку способствует улучшению кровообращения и трофики сердечной мышцы за счет развития процессов неоангиогенеза.

\section{Выводы}

В результате гистологического исследования миокарда молодых крыс с моделью АО было выявлено нарушение кровообращения, которое подтверждалось полнокровием и тромбозом сосудов, диапедезными кровоизлияниями, гипертрофией миокарда, интерстициальным и периваскулярным отеками, очаговым кардиосклерозом.

На фоне сочетанного использования РЭХВ $\left(-120^{\circ} \mathrm{C}\right)$ и криоконсервированных ЯСК КК отмечалась нормализация гистологической структуры сердца. Морфофункциональные признаки интерстициального отека, кардиосклероза и гипертрофии миокарда были слабо выражены, при этом снижалась степень жировой дистрофии миокарда. В интерстициальной соединительной ткани наблюдались диффузное распространение гистиоцитов, пролиферация фибробластов, формированных капилляров, что свидетельствовало об улучшении кровообращения и трофики мышцы сердца за счет компенсаторного развития процессов неоангиогенеза.

\section{Литература}

1. Агаджанян Н.А., Быков А.Т., Медалиева Р.Х. Состояние неспецифических адаптационных реакций организма и уровней здоровья при различных режимах экстремальных криогенных тренировок. Экология человека 2012; 10: 28-33.

2. Анисимова Е.В., Козлова И.В., Волков С.В. и др. Патология органов пищеварения при ожирении (обзор). Саратовский науч.-мед. журнал 2011; 7(4): 851-856.

3. Бабийчук В.Г., Марченко В.С., Бабийчук Г.А. Холодовой стресс как фактор коррекции функциональной архитектоники гематоэнцефалического барьера старых крыс. Проблемы криобиологии и криомедицины 2012; 22(2): 107-117.

4. Бабийчук Л.В., Коваль С.Н., Бабийчук Г.А. Структура миокарда молодых гипертензивных крыс после введения криоконсервированных ядросодержащих клеток кордовой крови человека. Проблемы криобиологии и криомедицины 2016; 26(3): 271-287.

5. Бабійчук Г.О., Козлов О.В., Ломакін І.І. та ін. Кріокамера для експериментального охолодження лабораторних тварин. Патент України № 40168. 2009 березень 25.

6. Бабійчук Л.О., Грищенко В.І., Рязанцев В.В. та ін. Спосіб виділення ядровмісних клітин кордової крові. Патент України № 234999. 2007 травень 25.

7. Бабійчук Л.О., Грищенко В.І., Гуріна Т.М. та ін. Спосіб кріоконсервування ядровмісних клітин кордової крові, у тому числі стовбурових гемопоетичних клітин. Патент України № 92227. 2010 жовтень 11.

8. Баранов В.Г., Баранов Н.Ф., Беловинцева М.Ф. Чувствительность к инсулину, толерантность к глюкозе и инсулиновая активность крови у крыс с алиментарным ожирением. Проблемы эндокринологии 1972; 6: 52-58. allows normalizing the structure of the heart muscle, in terms of improvement of blood circulation and trophism of the heart muscle presumably through the development of neoangiogenesis processes.

\section{Conclusions}

As a result of histological examination of the myocardium of young rats with the experimental AO, a circulatory disturbance was revealed, which was confirmed by the plethora and thrombosis of the vessels, diapedesis hemorrhages, hypertrophy of the myocardium, interstitial and perivascular edemas, focal cardiosclerosis. On the background of a combined use of RECE $\left(-120^{\circ} \mathrm{C}\right)$ and cryopreserved CBNCs, normalization of the structure of the heart was noted. Morphofunctional signs of interstitial edema, cardiosclerosis and myocardial hypertrophy were weakly expressed, while the fatty myocardial dystrophy was decreased. In the interstitial connective tissue the diffuse spread of histiocytes, proliferation of fibroblasts, formed capillaries were found, that was an evidence of an improvement of blood circulation and trophism of the heart muscle due to compensatory development of the neoangiogenesis processes.

\section{References}

1. Agajanyan N.A., Bykov A.T., Medalieva R.Kh. Condition of nonspecific adaptable reactions of the organism and health levels at various modes of extreme cryogenic trainings. Human Ecology 2012; 10: 28-33.

2. Anisimova E.V., Kozlova I.V., Volkov S.V. et al. Pathology of digestive organs at adiposity (review). Saratov Journal of Medical Scientific Research 2011; 7(4): 851-856.

3. Babijchuk L.V., Koval S.N., Babijchuk G.A. Structure of myocardium of young hypertensive rats after injection of cryopreserved human cord blood nucleated cells. Probl Cryobiol Cryomed 2016; 26(3): 271-287.

4. Babiychuk G.O., Kozlov O.V., Lomakin I.I. et al. Cryochamber for experimental cooling of laboratory animals. Patent of Ukraine $\mathrm{N}$ 40168. 2009 March 25.

5. Babiychuk L.A., Grishchenko V.I., Gurina T.M. et al. The method of cryopreservation of cord blood nucleated cells, including hematopoietic stem cells. Patent of Ukraine № 92227. Oct. 11.

6. Babiychuk L.A., Grishchenko V.I., Ryazantsev V.V. et al. The method of allocation of cord blood nucleated cells. Patent of Ukraine № 234999. 2007 May 25.

7. Babiychuk V.G., Marchenko V.S., Babiychuk G.A. Cold stress as corrector of functional architecture of blood brain barrier in aged rats. Probl Cryobiol and Cryomed 2012; 22(2): 107-117.

8. Baranov V.G., Baranov N.F., Belovintseva M.F. Sensitivity to insulin, glucose tolerance and insulin activity of blood in rats with alimentary obesity. Problems of Endocrinology 1972; 6: 52-58.

9. Belenkov Yu.N., Privalov E.V., Chekneva I.S. Cell therapy of chronic heart failure: types of stem cells used the results of recent clinical studies. Cardiology and cardiovascular disease 2008; 5: 4-18.

10.Bleakley C.M., Bieuzen F., Davison G.W. et al. Whole-body cryotherapy: empirical evidence and theoretical perspectives. Open Access J Sports Med 2014; 5: 25-36. 
9. Беленков Ю.Н., Привалова Е.В., Чекнева И.С. Клеточная терапия в лечении хронической сердечной недостаточности: виды применяемых стволовых клеток, результаты последних клинических исследований. Кардиология и сердечнососудистой хирургия 2008; 15(5): 4-18

10.Глюкман Э.Д. Пуповинная кровь как альтернативный источник гемопоэтических стволовых клеток для трансплантации Клеточная трансплантология и тканевая инженерия 2011; 6(1): 12-14.

11.Кондаков И.К., Коваль С.Н., Снегурская И.А. и др. К проблеме патогенеза метаболического синдрома. Жировая ткань и маркеры острой фразы воспаления. Артериальная гипертензия 2009; 3(5): 39-43.

12.Кочегура Т.Н., Ефименко А.Ю., Акопян Ж.А. и др. Клеточная терапия сердечной недостаточности: клинический опыт, проблемы и перспективы. Клеточная трансплантология и тканевая инженерия 2010; 5(2): 11-18.

13.Менделевич Д.М., Гришкина М.Н. Психические расстройства при алиментарном ожирении. Казан. мед. журнал 2004; 85(5): 363-366.

14.Олейник О.А., Самойлова Ю.Г., Ворожцова И.Н. и др. Клиникометаболические и молекулярно-генетические механизмь формирования кардиоваскулярных осложнений при ожирении. Сиб. мед. журнал 2011; 26(4): 16-21.

15.Петренко А.Ю., Грищенко В.И. Трансплантация стволовых клеток-перспективное направление терапии XXI. Стволовые кроветворные клетки из разных источников. Междунар. мед. журнал 2003; 1: 123-129.

16.Саркисов Д.С., Петров Д.С. Микроскопическая техника. М.: Медицина; 1996; 544 с.

17.Струков А.И., Серов В.В. Патологическая анатомия. М.: Медицина; 1993; 688 с.

18.Чернявська О.О., Мамонтов В.В., Бабійчук В.Г. та ін. Спосіб корекції вегетативних порушень організму експериментальних тварин з аліментарним ожирінням. Патент України № 108528. 2016 липень 25.

19.Чумакова Г.А., Веселовская Н.Г., Козаренко А.А. и др. Особенности морфологии, структуры и функции сердца при ожирении. Рос. кардиолог. журнал 2012; 4(96): 93-99.

20.Bleakley C.M., Bieuzen F., Davison G.W., Costello J.T. Wholebody cryotherapy: empirical evidence and theoretical perspectives. Open Access Journal of Sports Medicine 2014; 5: 25-36.

21.Bykov A.T., Rybkina V.A., Kovalenko V.V. Hemodynamics State at Different Modes of Systemic Air Cryogenic Exposure. European Researcher 2012; 34(11): 1929-1934.

22.Rymaszewska J., Tulczynski A., Zagrobelny Z., Kiejna A., Hadrys T. Influence of whole body cryotherapy on depressive symptoms - preliminary report. Acta Neuropyschiatrica 2003; 15 $122-128$
11. Bykov A. T., Rybkina V. A., Kovalenko V. V. Hemodynamics state at different modes of systemic air cryogenic exposure. European Researcher 2012; 34(11): 1929-1934.

12.Chernyavskaya E.A., Babiychuk V.G., Mamontov V.V. et al. Method of correction of vegetative disorders of the body of experimental animals with alimentary obesity. Patent of Ukraine N 108528. 2016 July 25

13. Chumakova G.A., Veselovskaya N.G., Kozarenko A.A. et al. Heart morphology, structure, and function in obesity. Russian Journal of Cardiology 2012; 4(96): 93-99.

14. Gluckman E.D. Cord blood as the source of hemopoietic stemcells for transplantation. Cellular Transplantation and Tissue Engineering 2011; 6(1): 12-14.

15.Kochegura T.N., Efimenko A.Y., Akopyan Zh.A. et al. Stem cell therapy of heart failure: clinical trials, problems and perspectives. Cellular Transplantation and Tissue Engineering 2010; 5(2): 11-18.

16.Kondakov I.K., Koval S.N., Snegurskaya I.A. et al. To the problem of metabolic syndrome pathogenesis. Adipose tissue and markers of acute inflammation phase. Arterial Hypertension 2009; 3(5): 39-43.

17.Mendelevich D.M., Grishkina M.N. Mental disorders in alimentary obesity. Kazan Med J 2004; 85(5): 363-366.

18. Oleynik O.A., Samoylova Y.G., Vorozhtsova I.N. Clinical metabolic and molecular genetic mechanisms of formation of cardiovascular complication in obesity. Sib Med J 2011; 26(4): 16-21.

19.Petrenko A.Yu., Grischenko V.I. Transplantation of stem cells - a promising direction of the xxi century therapy. Stem hemopoietic cells from different sources. IMJ 2003; 1: 123-129.

20. Rymaszewska J., Tulczynski A., Zagrobelny Z. et al. Influence of whole body cryotherapy on depressive symptoms - preliminary report. Acta Neuropyschiatrica 2003; 15: 122-128.

21.Sarkisov D.S., Petrov D.S. Microscopic techniques. Moscov: Medicine; 1996; 544 p.

22.Strukov A.I., Serov V.V. Pathologic anatomy. M.: Me-dicine; 1993; 688 p. 